UDC 341.783

CERIF: S150

\author{
Marko Novaković, $\mathrm{PhD}^{*}$
}

\title{
SOME REMARKS REGARDING THE PROCEDURE OF THE APPOINTMENT OF THE SECRETARY GENERAL OF THE UNITED NATIONS
}

Appointing Secretary-General is a process that has always been enshrined in secrecy. In 2016, due to reforms in the appointment process instigated by the president of the Security Council Mogens Lykketoft, more inclusion and transparency have been achieved, with the non-state actors being much more involved in the process. In the procedure itself, first five straw polls suggested that Antonio Guterres will be the new Secretary-General and this proved to be truth. Will this more transparent system result in appointment of the most appropriate candidate is the question that will be partially answered. In this article we will try to assess how much is done towards this goal and what still needs to be done. Moreover, we will investigate some aspects of the appointment procedure and pressing issues that Antonio Guterres will have to face.

Key words: $\quad$ Secretary General. - Antonio Guterres. - Geographical rotation. Straw polls. - Appointment procedure.

\section{INTRODUCTION}

Secretary-General (SG) of the United Nations (UN) Ban Ki-moon has been recently described as deplorable, irrelevant ${ }^{1}$ and generally considered incompetent. However, position itself is a position of the utmost importance - but those are big shoes to fill. Personality, overall qualities

* Research Fellow at the Institute of International Politics and Economics, Belgrade, marko@diplomacy.bg.ac.rs.

1 "Disquiet grows over performance of Ban Ki-moon, UN's 'invisible man"”, https://www.theguardian.com/world/2010/jul/22/ban-ki-moon-secretary-general-un, last visited 28 September 2016. 
and general profile of a person of the SG contributes a lot to the position itself as well as to the reputation and strength of the UN. Sole fact that only 8 people have been appointed SG of the UN in the organization's 70 years long history demonstrates how hard is to reach to this position. Being at the helm of the Secretariat that comprises around 44,000 members brings huge responsibility and requires immense devotion from their leader. External role of the SG is even harder, political one, with the necessity of balancing different streams, different influences: personal, political, institutional and national. Special place is taken by an administrative $^{2}$ function of the SG, including its function as a depositary. ${ }^{3}$ That is why selecting appropriate candidate for SG is a quest of the utmost importance. Ever-standing question is to whom this person should be adequate. Are the interests of major nations similar or at least compatible with the ones of smaller economies and are their interests corresponding with the UN vision of appropriate candidate? Is politician, diplomat or professional of some other kind most adequate for this position? These and many other questions are actualized every time when SG is appointed. In 2016 with more transparent appointment process and increased polarization at the international scene, choosing worthy candidate was more important than ever in the last 25 years. Did more transparent system contribute to the appointment of the most appropriate candidate? In Mr. Antonio Guterres will be something that can be assessed after his mandate is over. But appointing the best possible candidate in the most transparent way is the process that started in 2016 and hopefully there is no coming back to the system of appointment at the beginning of the UN.

\section{OVERVIEW OF THE PROCEDURE FOR THE APPOINTMENT OF THE SG}

UN Charter (Charter) regulates the procedure of the appointment of the SG in a very minimalistic manner. In the article 97 of the Charter it is stated that "The SG shall be appointed by the General Assembly upon the recommendation of the Security Council."4 This minimalist approach is not at all unusual for the Charter. Charter is a basic document and it is not envisaged to regulate all the aspects or all the procedures in detailed manner. When it was written, Charter was founding instrument of a new organization that emerged in the post-World War II arena. UN

2 I.C.J. Judgment of 12 April 1960, Right of Passage over Indian Territory (Portugal v. India)

3 B. Milisavljević, "Depozitar kod višestranih međunarodnih ugovora", Pravni život 12/2012. 303-317.

4 Article 97, UN Charter. 
founding fathers had to leave enough room for the organization to evolve and since nobody could predict how the world will look like in next decade or a century, the Charter had to be capable to survive the test of time. After 70 years, Charter still stands as a very current and applicable document that endured very few changes and it is due to its flexibility and adaptability.

At the San Francisco conference in $1945^{5}$ there were several ideas how the appointment process of the SG should look like. Honduras suggested that General Assembly should elect SG without the interference of the other UN organs. ${ }^{6}$ This suggestion of course did not stand a chance, since it would limit the influence of major powers in this very important question. Uruguay suggested that SG should be chosen by General-Assembly from the list of three candidates comprised by Security Council, while Mexico proposed that the SG should be chosen by General Assembly, on a suggestion of Security Council. ${ }^{7}$ Uruguay's suggestion was not accepted due to the recommendation of the General Assembly that Security Council should put only one candidate before them, in order to avoid public debate ${ }^{8}$ and thus further confrontation in the General Assembly. This is why one of the requests - to have two or more candidates to the General Assembly is not considered. ${ }^{9}$ As a matter a fact General Assembly accepted all candidates for SG by acclamation, except in 1950 when there was actual voting. ${ }^{10}$ Mexico's proposition was later accepted but not before two clarifications were adopted as well. One was that simple majority of votes in Security Council is enough for the candidate to be proposed. The other one is that question of the appointment of the SG should be considered as substantial rather than procedural question. ${ }^{11}$ Since the appointment of the SG was substantive question, negative votes of the permanent members of Security Council ${ }^{12}$ got the strength of the veto. ${ }^{13}$ At the San Francisco conference, several countries including Netherlands,

5 1945: The San Francisco Conference, http://www.un.org/en/sections/historyunited-nations-charter/1945-san-francisco-conference/index.html, last visited 22 September 2016.

6 O. Šuković, Položaj i uloga generalnog sekretara Ujedinjenih nacija, Institut za međunarodnu politiku i privredu, Beograd 1967, 11.

7 Ibid.

8 "Who wants to rule the world?", http://www.straitstimes.com/opinion/whowants-to-rule-the-world, last visited 22 September 2016.

9 http://www.1for7billion.org/why/, last visited 25 September 2016.

10 L. Sievers and S. Daws, The procedure of the UN Security Council, Oxford University Press, Oxford $2014^{4}, 404$.

11 O. Šuković, 22.

12 In the text permanent members of the Security-Council will be referenced as P-5

13 Article 27 of the UN Charter. 
Canada, Belgium and Australia insisted that appointment of SG should be regarded as a procedural matter, insisting that if the power of veto is given to the permanent Security Council members, the independence of the SG would be jeopardized and diminished. ${ }^{14}$ The fact is that Security Council members have more power in electing SG and this imparity influence is often criticized as inequitable ${ }^{15}$ and undemocratic. ${ }^{16}$ However, there are at least two reasons why this bigger influence of the P-5 is justified and fair. On the one side, SG will definitely have to cooperate and find common grounds first of all with Permanent Members of Security Council. Consequently it is better for the functioning of the Organization and to him personally to be approved with non-usage of veto then to obstruct him/her in every step and thus effectively stultify the appointment. On the other hand, even a brief look at the financing scheme of the UN will show us another reason that justifies this inequality between P-5 members and other UN members. It is illusory and even unfair to expect that country such as USA that finances $22 \%$ of the entire UN budget, to have the same voting power in every question as countries with virtually none contribution. At first 9 places of the list of the contributors, there are all 5 permanent members: USA (22.000), China (7.921), France (4.859), United Kingdom (4.463), and Russian Federation (3.088). Apart for them, there are three former Axis powers - Italy (3.748), Japan (9.680) and Germany (6.389) and one country aspiring to become permanent member - Brazil (3.823). ${ }^{17}$ P-5 members are financing $42.331 \%$ of UN budget, so their bigger influence is well financially founded.

\section{MORE TRANSPARENT APPOINTMENT PROCEDURE}

A lack of transparency and inclusion of the appointment procedure of the SG has been often criticized. ${ }^{18}$ In 1997 the General Assembly recognized that greater level of transparency was indeed desirable at the appointment process of the SG and it decided in the resolution 51/241 that the process of selection of the SG shall be made more transparent. It also established the role for the President of the General Assembly in identifying potential candidates. Critiques regarding the election system happens

14 UNCIO, Vol. 8, Doc. 471/II/1/17, наведено према О. Шуковић, 40.

15 T. Weiss, "Overcoming the Security Council Reform Impasse: The Implausible versus Plausible", Dialogue on Globalization (Occasional Paper) 14/2005.

16 J. S, Lund, Pros and Cons of Security Council reform, Center for UN Reform Education, Wayne, New Jersey 2010.

17 United Nations Secretariat, Assessment of Member States' advances to the Working Capital Fund for the biennium 2016-2017 and contributions to the United Nations regular budget for 2016, ST/ADM/SER.B/932, 28 December 2015.

18 Security Council Report, Special Research Report - Appointment of the New Secretary General, 3. 
far not only from the eyes of the public, but away from many states, prompted the response of the UN General Assembly. On September 22th 2015 General Assembly passed the resolution 69/321 and thus started implementing ideas of making election more transparent.

At the $7539^{\text {th }}$ Security Council meeting $(\mathrm{SC} / 12088)$ on $20^{\text {th }}$ October 2015, among topics addressed by speakers was appointment procedure of the SG. ${ }^{9}$ María Emma Mejía Vélez from Colombia stated that the holding of Arria Formula meetings ${ }^{20}$ on candidates for that post demonstrates that the wider UN membership was more involved in the Council's work. This process (named after Ambassador Diego Arria, representative of Venezuela on the Security Council (1992-1993) is very informal and enables Security Council members to exchange of views with candidates. ${ }^{21}$ Mogens Lykketoft, not long after being elected for the president of the UN General Assembly on 15 June 2015, ${ }^{22}$ put an effort to make election of the SG more transparent and more inclusive. As he committed to running his Presidency in the most open and transparent manner possible he also tried to apply this manner of work to the process of electing and appointing of the next UNSG. ${ }^{23}$

Mr Lykketoft institutionalized several guidelines in order to promote interactive nature of meetings, such as encouraging Member States to pose short, focused questions, requesting them to limit any intervention to a maximum of 2 minutes (groups to 3 ). In the quest to enhance transparency, meetings were open and webcasted in all official languages. In order to improve inclusivity, 1-2 representatives from civil society were given floor. ${ }^{24}$ Afterwards, each candidate was given a two-hour televised and webcast time slot. Prior to opening up the floor for questions from UN delegates, civil society representatives and the public through social media, candidates gave short oral presentations - their vision statements - addressing challenges and opportunities facing the UN and the next $\mathrm{SG}^{25}$ One can with certainty state that inclusion and transparency was improved in 2016 but that these reforms did not make the procedure

19 Speakers Focus on Veto Power, Appointment of Next Secretary-General, Cooperation among UN and Regional Bodies as Security Council Debates Working Methods, http://www.un.org/press/en/2015/sc12088.doc.htm, last visited 16 June 2016.

20 Background Note on the "Arria-Formula" Meetings of the Security Council Members, http://www.un.org/en/sc/about/methods/bgarriaformula.shtml, last visited 14 June 2016.

21 Ibid.

22 President of the seventieth session of the United Nations General Assembly H.E. Mr. Mogens Lykketoft, http://www.un.org/en/ga/70/presskit/, last visited 11 July 2016.

23 General Assembly of the United Nations, Procedure of Selecting and Appointing the next UN Secretary-General.

24 Ibid.

25 UN News Center, The next UN Secretary-General: Assembly President says 'new standard of transparency' established, http://www.un.org/apps/news/story.asp? News $I D=53695 \#$.V9lFlPl974Y, last visited 7 July 2016 . 
transparent. UN should strive to reach higher level of transparency but at the same time, public have to be aware that some degree of secrecy will be necessary. No one should be in fallacy - election of SG will always be, at least in this UN format, in the hands of the P-5 members but with clear rules and more transparent and inclusive procedure of appointment SG would have to be competent in order to be legitimate.

\subsection{Vision statements - shouldn't the UN start the change from itself?}

In the history of the UN, there is probably nothing more shameful and appalling than atrocities committed by the UN troops among which especially abominating are those committed to the children in general but especially to the children in armed conflicts. ${ }^{26}$ This issue was mentioned by Mr. Jeremić in one general manner, alongside with other reforms of UN Secretariat ${ }^{27}$ although he, commendably, noted the importance of the protection of the whistleblowers. ${ }^{28}$ In the statements of Ms. Gherman ${ }^{29}$ and Ms. Figueres ${ }^{30}$ this problem was addressed more specifically. Candidates that gave appropriate attention to th UN troop's atrocities (both in wording and merit) are Mr. Türk ${ }^{31}$ and Mr. Lajčák. ${ }^{32}$ Absolute silence regarding this question by Ms. Bokova, ${ }^{33}$ Ms. Clark, ${ }^{34}$ Mr.Lukšić, ${ }^{35}$

26 Šurlan T. "Legal status and protection of children in armed conflicts: New tendencies", Bezbednost 3/2012, 121-137.

27 Vision Statement Serbia, http://www.un.org/pga/70/wp-content/uploads/sites/10/ 2016/01/12-April_Vision-Statement-Serbia.pdf, last visited 6 July 2016.

28 Vision Statement Serbia, http://www.un.org/pga/70/wp-content/uploads/sites/10/ 2016/01/12-April_Vision-Statement-Serbia.pdf, last visited 6 July 2016.

29 Vision Statement Costa Rica, http://www.un.org/pga/70/wp-content/uploads/ sites/10/2016/01/Costa-Rica-Vision-Statement-1.pdf, last visited 6 July 2016.

30 Vision Statement Moldova, 2, http://www.un.org/pga/70/wp-content/uploads/ sites/10/2016/01/Secretary-General-Election-Vision-Statement_Moldova-7-April-2016. $p d f$, last visited 6 July 2016.

31 Vision Statement Slovenia, 2, 4, http://www.un.org/pga/70/wp-content/uploads/ sites/10/2016/01/4_April_Secretary-General-Election-Vision-Statement_Slovenia-4-April2016.pdf, last visited 6 July 2016.

32 Vision Statement Slovakia, http://www.un.org/pga/70/wp-content/uploads/sites/ 10/2016/01/Secretary-General-Election-Vision-Statement_Slovakia-2-June.pdf, last visited 6 July 2016.

33 Vision Statement Bulgaria, http://www.un.org/pga/70/wp-content/uploads/sites/ 10/2016/01/6_AprilSecretary-General-Election-Vision-Statement_Bulgaria-6-April-2016. pdf, last visited 6 July 2016.

34 Vision Statement Helen Clark, http://www.un.org/pga/70/wp-content/uploads/ sites/10/2016/01/8-April_Helen-Clark-Vision-Statement-ENGLISH-FRENCH.pdf, last visited 6 July 2016.

35 Vision Statement Montenegro, http://www.un.org/pga/70/wp-content/uploads/ sites/10/2016/01/5_April_Secretary-General-Election-Vision-Statement_Montenegro-5April-20161.pdf, last visited 6 July 2016. 
Mr.Kerim ${ }^{36}$ and Ms. Pusić ${ }^{37}$ criticizes them more loudly than any article could. The biggest disappointment in this regard was Ms. Malcorra. Despite the fact that she was Under-SG of the UN for Field Support she practically did not mention the question of UN troops outrageous misconduct, ${ }^{38}$ and although she gave more attention to this in the informal dialogue $^{39}$ her overall address just demonstrates unwillingness to change the UN approach regarding this painful matter. New SG, Mr. Guterres addressed this issue in one, although emphasized, sentence ("People in need of protection are not getting enough. The most vulnerable, such as women and children, are an absolute priority" ${ }^{\prime 0}$ ).

It is understandable that due to specific, general nature of the vision statements, limited space and huge number of topics, not all of them could be covered, but protecting the part of the world population that virtually does not have any chance of protecting themselves has always been huge issue both in national and international level and as such it must be at the top of the priority to every national and international actor. This especially relates to the UN, because some of the darkest moments in the UN history are committing and covering up atrocities to the children by members of peace keeping missions. The most recent example where UN not only failed to stop and failed to prosecute members of a mission that raped children in Central African Republic, but actually suspended the whistleblower Mr. Anders Kompass, ${ }^{41}$ leaves no space of avoiding this issue. It is unclear where from the UN and next SG will derive its authority to instruct countries to improve position of children and women, when their own troops are becoming notorious for their atrocities to those groups. UN is becoming as much notorious for the failure to react appropriately - reacting by processing the whistleblowers. While world's problems such as Syria crisis, refugee crisis and ever-

36 Vision Statement Montenegro, http://www.un.org/pga/70/wp-content/uploads/ sites/10/2016/01/Secretary-General-Election-Vision-Statement_FYR-of-Macedonia-6April-2016.pdf, last visited 6 July 2016.

37 Vision Statement Croatia, http://www.un.org/pga/70/wp-content/uploads/sites/ 10/2016/01/Secretary-General-Election-Vision-Statement_Croatia-5-April-2016.pdf, last visited 6 July 2016.

38 Vision Statement Malcorra, http://www.un.org/pga/70/wp-content/uploads/sites/ 10/2016/01/Vision-Statement-Malcorra.pdf, last visited 6 July 2016.

39 Informal Dialogue Malcorra, http://webtv.un.org/search/susana-malcorra-argentina-informal-dialogue-for-the-position-of-the-next-un-secretary-general/4931454866 001?term=malcorra, last visited 6 July 2016.

40 Vision Statement Portugal, 3, http://www.un.org/pga/70/wp-content/uploads/ sites/10/2016/01/4-April_Secretary-General-Election-Vision-Statement_Portugal-4-April20161.pdf, last visited 6 July 2016.

41 M. Novaković, "Position Of The Whistleblowers In The United Nations System 10 Years After Secretary-General's Bulletin On Protection Against Retaliation - How Far Have We Come?", Social Change in the Global World (ed. Strasko Stojanovski), 2016. 
present terrorism hazard is something that Mr.Guterres have to address immediately on the external level, internally there is no more pressing concern than reforming the UN system and preventing those atrocities happen ever again.

\subsection{Straw Polls}

Straw polls were covered very vividly by the world media and thus it was much easier to find their results then ever before. Straw polls as a way of narrowing down SG job candidates were developed in 1981 by Olara Otunnu of Uganda, at that time president of the Security Council. ${ }^{42}$ Colored ballots were first introduced in $1991^{43}$ to differentiate votes equipped with veto power (red) from negative votes given by non-permanent Security Council members. This practice has been formalized as a set of guidelines in November 1996 and since then they are known as the 'Wisnumurti Guidelines,' named after Ambassador Nugroho Wisnumurti of Indonesia who held the rotating presidency of the Security Council when the guidelines were set. These straw polls continue until there is a majority candidate without a single veto from a permanent member of the Security Council. ${ }^{44}$ Some permanent Security Council members insisted that it is very important for the straw polls results to remain secret. Straw polls are not envisaged to be public - and de iure they are not butresults of the straw polls are leaked so promptly, that one can doubt that leaking was allowed to occur.

Table no. 1: Results of the First Straw Poll - July $21^{\text {st }} 2016$

\begin{tabular}{|r|l|c|c|c|}
\hline & \multicolumn{1}{|c|}{ Candidate } & Encourage & No Opinion & Discourage \\
\hline 1 & António Guterres & 12 & 3 & 0 \\
\hline 2 & Danilo Türk & 11 & 2 & 2 \\
\hline 3 & Irina Bokova & 9 & 2 & 4 \\
\hline 4 & Vuk Jeremić & 9 & 1 & 5 \\
\hline 5 & Srgjan Kerim & 9 & 1 & 5 \\
\hline 6 & Helen Clark & 8 & 2 & 5 \\
\hline
\end{tabular}

42 Research Report Appointing the UN Secretary-General: The Challenge for the Security Council, 2016, No. 4.

43 Ibid.

44 "Selecting a new UN Secretary-General: a job interview in front of the whole world", http://www.un.org/apps/news/story.asp?NewsID=53641\#.V9lFnfl974Y, 6. 7. 2016. 


\begin{tabular}{|r|l|c|c|c|}
\hline & \multicolumn{1}{|c|}{ Candidate } & Encourage & No Opinion & Discourage \\
\hline 7 & Miroslav Lajčák & 7 & 5 & 3 \\
\hline 8 & Susana Malcorra & 7 & 4 & 4 \\
\hline 9 & Christiana Figueres & 5 & 5 & 5 \\
\hline 10 & Natalia Gherman & 4 & 7 & 4 \\
\hline 11 & Igor Lukšić & 3 & 5 & 7 \\
\hline 12 & Vesna Pusić & 2 & 2 & 11 \\
\hline
\end{tabular}

Table no. 2: Results of the Second Straw Poll, August $5^{\text {th }} 2016$.

\begin{tabular}{|r|l|c|c|c|}
\hline & \multicolumn{1}{|c|}{ Candidate } & Encourage & No Opinion & Discourage \\
\hline 1 & António Guterres & 11 & 2 & 2 \\
\hline 2 & Vuk Jeremić & 8 & 3 & 4 \\
\hline 3 & Susana Malcorra & 8 & 1 & 6 \\
\hline 4 & Irina Bokova & 7 & 1 & 7 \\
\hline 5 & Danilo Türk & 7 & 3 & 5 \\
\hline 6 & Srgjan Kerim & 6 & 2 & 7 \\
\hline 7 & Helen Clark & 6 & 1 & 8 \\
\hline 8 & Christiana Figueres & 5 & 2 & 8 \\
\hline 9 & Natalia Gherman & 3 & 2 & 10 \\
\hline 10 & Miroslav Lajčák & 2 & 7 & 6 \\
\hline 11 & Igor Lukšić & 2 & 4 & 9 \\
\hline 12 & Vesna Pusić & \multicolumn{3}{|c|}{ dropped out } \\
\hline
\end{tabular}


Table no. 3: Results of the Third Straw Poll - August $29^{\text {th }} 2016$.

\begin{tabular}{|r|l|c|c|c|}
\hline & \multicolumn{1}{|c|}{ Candidate } & Encourage & No Opinion & Discourage \\
\hline 1 & António Guterres & 11 & 1 & 3 \\
\hline 2 & Miroslav Lajčák & 9 & 1 & 5 \\
\hline 3 & Vuk Jeremić & 7 & 3 & 5 \\
\hline 4 & Irina Bokova & 7 & 3 & 5 \\
\hline 5 & Susana Malcorra & 7 & 1 & 7 \\
\hline 6 & Srgjan Kerim & 6 & 2 & 7 \\
\hline 7 & Helen Clark & 6 & 1 & 8 \\
\hline 8 & DaniloTürk & 5 & 4 & 6 \\
\hline 9 & Christiana Figueres & 2 & 1 & 12 \\
\hline 10 & Natalia Gherman & 2 & 1 & 12 \\
\hline 11 & Igor Lukšić & \multicolumn{3}{|c|}{ dropped out } \\
\hline 12 & Vesna Pusić & \multicolumn{3}{|c|}{ dropped out } \\
\hline
\end{tabular}

Table no. 4: Results of the Fourth Straw Poll - September $9^{\text {th }} 2016$.

\begin{tabular}{|r|l|c|c|c|}
\hline & \multicolumn{1}{|c|}{ Candidate } & Encourage & No Opinion & Discourage \\
\hline 1 & António Guterres & 12 & 1 & 2 \\
\hline 2 & Miroslav Lajčák & 10 & 1 & 4 \\
\hline 3 & Vuk Jeremić & 9 & 2 & 4 \\
\hline 4 & Irina Bokova & 7 & 3 & 5 \\
\hline 5 & Susana Malcorra & 7 & 1 & 7 \\
\hline 6 & Srgjan Kerim & 8 & 0 & 7 \\
\hline 7 & Helen Clark & 6 & 2 & 7 \\
\hline 8 & Danilo Türk & 7 & 2 & 6 \\
\hline 9 & Christiana Figueres & 5 & 0 & 10 \\
\hline 10 & Natalia Gherman & 3 & 1 & 11 \\
\hline 11 & Igor Lukšić & \multicolumn{3}{|c|}{ dropped out } \\
\hline 12 & Vesna Pusić & \multicolumn{3}{|c|}{ dropped out } \\
\hline \multicolumn{4}{|l|}{}
\end{tabular}


Table no. 5 September $26^{\text {th }} 2016$.

\begin{tabular}{|r|l|c|c|c|}
\hline & Candidate & Encourage & No Opinion & Discourage \\
\hline 1 & AntónioGuterres & 12 & 1 & 2 \\
\hline 2 & Vuk Jeremić & 8 & 1 & 6 \\
\hline 3 & MiroslavLajčák & 8 & 0 & 7 \\
\hline 4 & DaniloTürk & 7 & 0 & 7 \\
\hline 5 & Susana Malcorra & 7 & 0 & 7 \\
\hline 6 & Irina Bokova & 6 & 2 & 7 \\
\hline 7 & Helen Clark & 6 & 0 & 9 \\
\hline 8 & Srgjan Kerim & 6 & 0 & 9 \\
\hline 9 & Natalia Gherman & 3 & 1 & 11 \\
\hline 10 & Christiana Figueres & \multicolumn{3}{|c|}{ dropped out - September $12^{\text {th }}$} \\
\hline 11 & Igor Lukšić & \multicolumn{3}{|c|}{ dropped out - August $23^{\text {th }}$} \\
\hline 12 & Vesna Pusić & \multicolumn{3}{c|}{ dropped out - August $4^{\text {th }}$} \\
\hline
\end{tabular}

Chart no. 1:

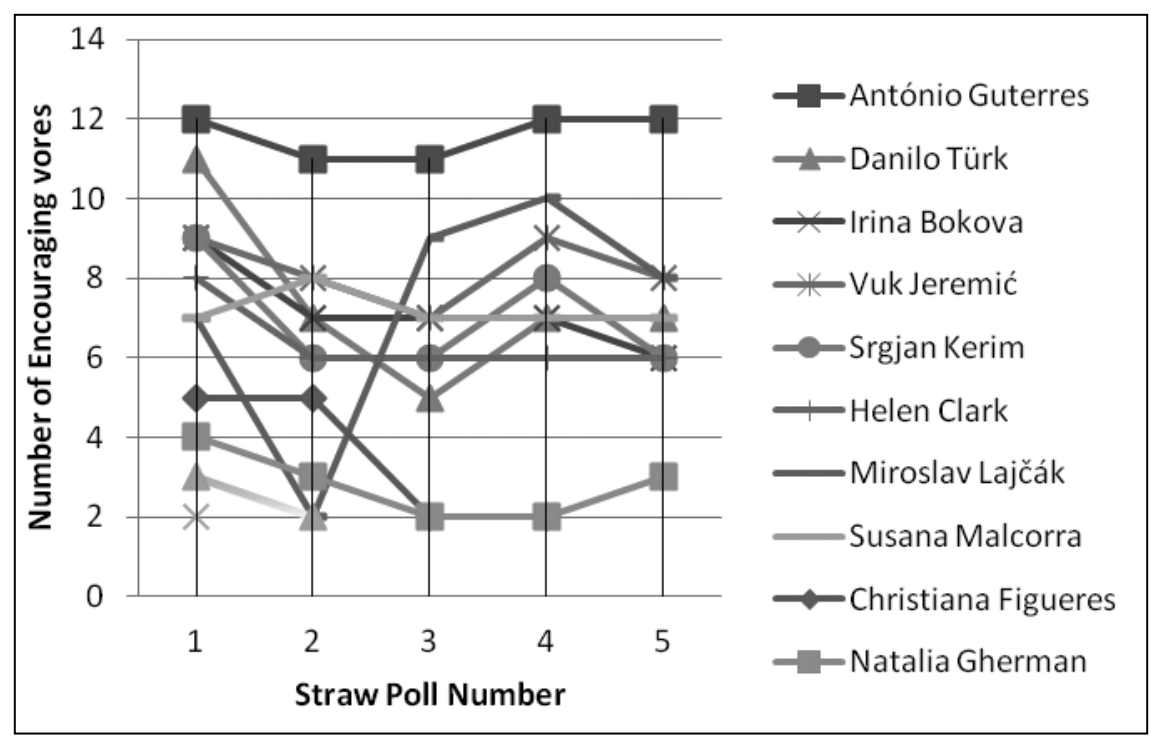


Chart no. 2:

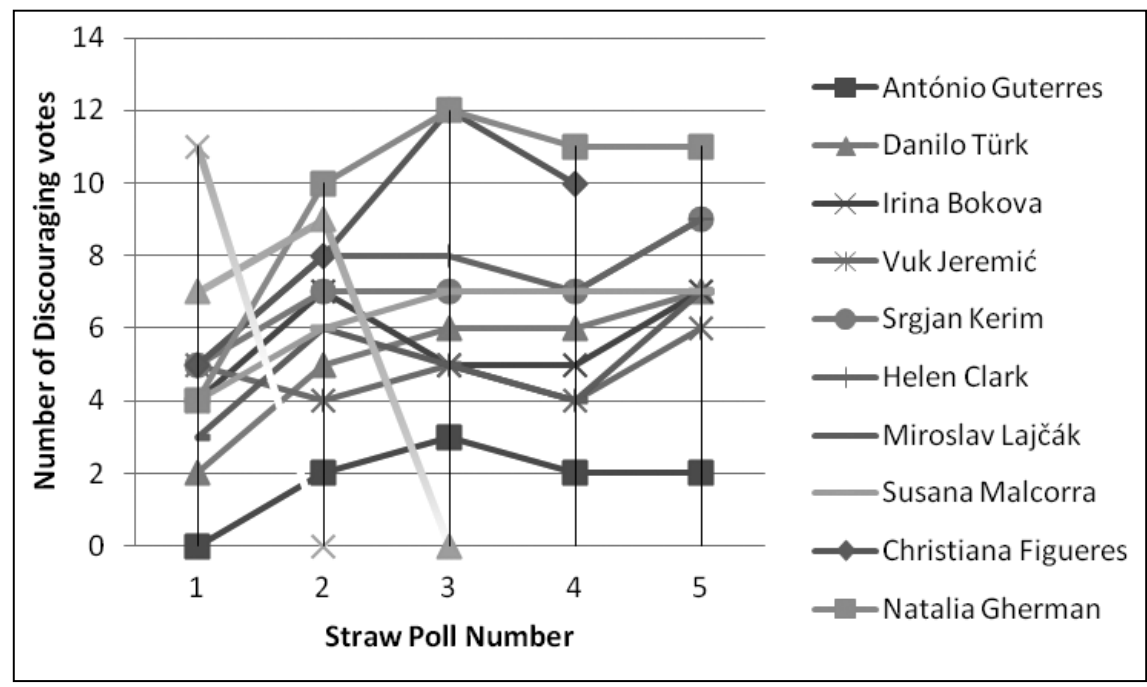

In order to explore the results more closely, we are presenting the two charts, each focusing on one of two most important aspects - first one is presenting number of encouraging votes by every candidate per poll, while the second one is presenting number of discouraging votes per poll. It has been noted that those are not actual votes, but rather general observations by Security Council members regarding candidates.

There was a lot of suspicion that first five straw polls were just stage for the negotiations. For example, we could see the willingness to negotiate in Russia's position that they think that the next SG should come from Eastern European group, but Russia also (officially) stated that they will not block candidate only because he is not coming from Eastern European group. ${ }^{45}$ Furthermore, since there is no deadline for the candidacy and no rule forbidding new candidates to enter the race at any time (as we saw at the example of Kristalina Georgieva) there was an open possibility for somebody other than already nominated candidates to be appointed for the position of the SG at any stage of the procedure. It could have happened that more than one candidate had one or more vetoes, as in 1996 when both Kofi Annan of Ghana and Amara Essy of Côte d'Ivoire had colored ballots. After seven rounds of straw polls, veto against Annan was dropped. ${ }^{46}$ Another scenario was that two or more

45 "Front runners emerge for U.N. chief from town halls with General Assembly" http://uk.reuters.com/article/uk-un-secretarygeneral-idUKKCNOXC2H7, last visited 22 July 2016.

46 B. Boutros-Ghali, Unvanquished, a United Nations-United States Saga, L.B. Tauris Publishers, London-New York 1999, 329. 
candidates do not have any red colored ballots. This situation occurred in 1991 when neither Boutros Boutros Ghali of Egypt nor Bernard Chidzero of Zimbabwe had any red-colored votes. In this case, the Council proceeded to vote formally on each of the two candidates, with BoutrosGhali emerging as the victor. ${ }^{47}$

The biggest surprise of 2016 appointment procedure was actually that most obvious thing happened, and it happened very fast. Clear leader in all stages was appointed SGafter first colored. This might not be the case in the future but this time public has feeling that not much of horsetrading happened behind the closed doors. Finally, some organizations are insisting on clear timetable for the appointment of the SG. ${ }^{48}$ While date and time of the straw polls should be arranged and publicly announced, deadline for the appointment of the SG is not necessarily good solution, because agreeing on SG should be the only goal. Forcing Security Council to rush into appointment, pressed by the deadline could potentially lead to the appointment of the candidate that is not the best one or appointment of the SG that would not have long-lasting support of the P5 members.

\section{MODELING SG ACCORDING TO THE "INFORMAL CRITERIA"}

If there wasa computer program that generates SG according to all the requests stated by relevant actors on the international stage in the last year, new SG would have been a woman from Eastern European group of countries, with experience in working the UN system, and life experience as well. Shaping the General Secretary towards these requirements will put aside the merit and need to look for a candidate with necessary substantial qualities and this is why these criteria should be disregarded. Showing lack of the legal basis of these criteria is an important task in the quest of transparent background and clarification of criteria in the future.

\subsection{Geographical Rotation}

From the early days of the UN, question whether SG should be a citizen of a country that is P-5 member or not was very vividly debated. ${ }^{49}$ At the San Francisco conference, Soviet Union proposed that the mandate

\footnotetext{
47 Ibid.

48 http://www. Ifor7billion.org/why/, last visited 6 July 2016.

49 League of Nations had three SGs namely Sir Eric Drummond from the United Kingdom (1926-1933), Joseph Avenol (1933-1940) from France and Seán Lester (19401946) from Ireland, aut.
} 
of the SG should be two years, thus enabling all P-5 members to have a SG during one decade. ${ }^{50}$ However, during the Cold War it would be extremely hard to find a person from P-5 members that would be acceptable for both blocks. Another issue was whether the person coming from these countries would be able to perceive and appreciate all the problems and needs of "small" countries. Consequently, there is mutual consensus, or we can say gentlemen's agreement between P-5 members not to nominate their own nationals for the SG position. Although this rule is not legally formalized this practice has been respected without a precedent for over 70 years now.

Another informal principle that was given much attention is appointing SG according to the geographical rotation. Some lawyers see legal foundation in this rule in article 101 of Charter of the UN, that states: "Due regard shall be paid to the importance of recruiting the staff on as wide a geographical basis as possible" but deriving rotation basis rule from this article is very far-fetched. Even that part XV of the Charter where article 101 is situated is in its entirety devoted to the Secretariat of the UN, and SG is not only member but also the chief and the most important figure of the Secretariat, in the first article of the part XV is stated that there is "clear distinction" between staff and $S G$ and consequently article 101 cannot apply to the SG. More precisely, article 101 is aimed for the SG to consider when he is appointing "upper echelons of the Secretariat", ${ }^{51}$ such as High Commissioner ${ }^{52}$ for example, and not as guidance for electing SG.

The issue of geographic rotation was particularly actualized in the late 1980's when African countries insisted that next SG should come from that continent. Eventually, their request was granted by electing Boutros Boutros-Ghali from Egypt, who started his mandate in 1992. However, this does not make geographical rotation prerequisite or obligation even in the widest sense. This is not a rule - not only because it is not formalized in any way but also because even practice regarding this question clearly denies even emerging rule of regarding the geographical rotation. SGs came from, respectively these blocks - Western European and Others (WEOG), Western European, Asia-Pacific, WEOG, Latin America \&Caribbean, Africa, Africa, Asia-Pacific and WEOG. There is also not much resemblance to the rotation system, if we look it through number of terms held by SGs as from certain UN regional group. Includ-

\footnotetext{
50 O. Šuković, 31

51 United Nations A/RES/42/220 General Assembly Distr. GENERAL 21 December 1987 ORIGINAL: ENGLISH A/RES/42/220 99th plenary meeting 21 December 1987.

52 C. Norchi, "Human Rights: A Global Common Interest", The United Nations: Confronting the Challenges of a Global Society (ed. J.E.Krasno), Lynne Rienner Publishers, London 2004, 89.
} 
ing the newest appointment of Mr. Guterres, Western European and Others group had 7 terms, Asia-Pacific, 4, Africa 3, Latin America \& Caribbean 2, and Eastern Europe none. And even if there is practice, practice itself without awareness of conforming to the legal obligation does not make something rule. ${ }^{53}$ In the practice of the UN, we can see that some other informal considerations were more important tnan the geographic rotation. For example, during the Cold War it was much more important that candidate is coming from the country and background neutral to major blocks. 54

Geographical rotation should not be perceived even as a consideration. There is no legal basis for that and also this consideration will not promote the best person to a SG position. The UN should strive to have the best candidate for these position criteria and not the best from certain part of the world. On the other hand, there are many other positions in the UN system where geographical consideration is more appropriate and not only at the highest posts. One of the issues where due to the financial costs is reserved for Western countries only is internship posts. According to the rules of many $\mathrm{UN}$ organizations, interns are not only obliged to pay all the accommodation, health insurance and living costs on their own but they are forbidden to do any jobs during their internships. ${ }^{55}$ Consequently, only people living in the vicinity of the UN New York, Vienna, Geneva and other major locations of the UN are able to attend this important internship and due to these rules instead of the best candidates are not the ones attending this practice. Putting aside the fact that geographical rotation is not a legal binding or an obligation in any way, chances for candidate from this group to be chosen in 2016 were diminished not only by some P-5 members but by the countries of this group as well.

First of all, since the new and to some point more transparent process of appointment was introduced, many of the countries rushed to have their own candidates even when they were aware that they do not have real chance. They did this in order to promote themselves and to achieve some short-sighted goals. Out of 12 candidates, 8 of them were candidates from the Eastern European group. This number of candidates from Eastern European group actually diminished already slim chances for a candidate from this group to be appointed by dissipating their lobbying and other capacities to 8 candidates.

Political situation in the Eastern Europe also damaged chances of candidates from this region. Migrant crisis, strengthening of the right-wing

53 International Court of Justice, North Sea Continental Shelf Casses, Judgment of 20 February 1969 , para. 77

54 L. Sievers and S. Daws, The procedure of the UN Security Council, Oxford University Press, Oxford $2014^{4}, 405$.

55 D. A. Mundis, "Practicing International Criminal Law", Careers in International Law (ed. S.A. Swartz), American Bar Association, Chicago, 122. 
parties, Russian sanctions are just some of the topics where it will be hard to remain neutral and not to antagonize any of the P-5 members. Once again, the Eastern Europe is a place of clash of western and eastern interests, and it is hard to stay neutral and not to antagonize major powers.

\subsection{Gender Equality}

Despite all UN proclamations insisting on gender equality and work through UNWOMEN activities for example, female SG is yet to be elected. The importance of appointment of a female SG has been stated at the Security Council's $7539^{\text {th }}$ meeting, where it was stated that "election of a female SG would mark a significant improvement and historic opportunity for change". The most radical in pursuing female SG was The Non-Alignment Movement (NAM), more precisely its ad-hoc working group, that suggested that only female candidate should been considered for the SG position in 2016. ${ }^{56}$

While there is no doubt that woman should be given equal opportunity and eventually chosen for the SG position, gender of the candidate (same as origin or UN experience) should not have any influence in electing next SG if we are trying to appoint the best person overall. Woman will be at the helm of the UN when P-5 members agree that that person is appropriate candidate not sooner or later.On the other hand, not appointing female SG in the next rounds will demonstrate that $\mathrm{UN}$ is not doing enough regarding empowerment of women.

The next SG appointment should not be designated for a woman, but instead UN and Mr. Guterres should work hard that in the next 5 years position of women is so drastically improved, that it is not so hard for the numerous excellent female candidates to participate in the race and thus be appointed.

\subsection{UN Experience}

One of the criteria that have been echoing diplomatic couloirs is that next SG should come within the organization. Vesna Pusić, one of the former candidates was of the same opinion and she even listed her lack of UN experience as one of the reasons for her withdrawal. ${ }^{57}$ Regardless of this being the real reason for her withdrawal, the fact is that three candidates that finished with fewest encouraging votes and biggest number of discouraging votes in the first straw poll are among ones without UN

56 http://www.unelections.org/?q=node/71, last visited 15 September 2016.

57 "Vesna Pusić Withdraws as Candidate for UN Secretary General", https://www. total-croatia-news.com/item/13428-vesna-pusic-withdraws-as-candidate-for-un-secretary-general, last visited 15 September 2016. 
experience ${ }^{58}$ Furthermore, two straw poll favorites Mr. Guterres and Mr. Jeremic came from the UN bodies.

None of these informal "criteria" should have bothered any candidate this year and should not bother them at all in the future - not only because they cannot change it, but rather because all of them are ultimately irrelevant and should remain that. At the example of Mr. Jeremić, his only obstacle was in the fact that he is not favored by several P-5 members. Some of his statements during his time as a Minister of Foreign Affairs and his presidency of the General Assembly especially regarding Kosovo's* independence ${ }^{59}$ and the critiques of the work of ICTY ${ }^{60}$ could prove very costly to his generally highly regarded candidacy. Jeremić's efforts to alter this picture of him were obvious. In the late stage of the race, we could see some very commendable articles in USA newspapers hailing Jeremić as the best candidate. ${ }^{61} \mathrm{He}$ was also trying to emphasize his not so well-known role in the fight against Slobodan Milosevic's regime, ${ }^{62}$ presenting himself as pro-western candidate. However, this proved not to be enough.

Overall quality of the candidate is the only criteria that should be relevant and since final decision will be reached by P-5 members it is very important that public is involved as much as possible in order to at least pressure the appointment of the best and prevent appointment of somebody who is obviously below the standards.

\subsection{Antonio Guterres as a SG}

On the shoulders of Mr. Guterres is great responsibility and high expectations as a SG. Formally, he seems a good candidate in general, being also equipped with appropriate skills to tackle current world issues. $\mathrm{He}$ is experienced in high politics since he was Prime minister of Portugal, experienced in UN experience with a 10 year experience as a UN High Commissioner for Refugees, respected even by his opponents, ${ }^{63}$ favorable by all major powers.

58 Table 1 and 2.

59 "Jeremić: Kosovo will join UN over my dead body", http://www.b92.net/eng/ news/politics.php?yyyy $=2012 \& m m=07 \& d d=11 \& n a v \_i d=812111$, last visited 6 July 2016.

60 UNGA president's Serbian nationalism rankles Western powers, http://foreignpolicy.com/2013/03/25/unga-presidents-serbian-nationalism-rankles-western-powers/.

61 "A Different Kind of UN Secretary General", http://nationalinterest.org/feature/ different-kind-un-secretary-general-17839, last visited 6 July 2016.

62 "Who Will Run the U.N.? The best choice for reform at Turtle Bay is Serbia's Vuk Jeremic", http://www.wsj.com/articles/who-will-run-the-u-n-1474236158, last visited 27 September 2016.

63 "Antonio Guterres, the Man Who May Become the Next UN Secretary-General", http://thewire.in/53385/antonio-guterres/, last visited 5 September 2016. 
He did well in the informal dialogues but also showed his political versatility in avoiding giving up to much. One of the questions was regarding independence as a SG - certainly crucial issue for every high position and especially for the position of the SG. Mr. Guterres insisted that independence is not matter of measures taken but rather of the attitude and that he can't avoid pressure but he can resist one. ${ }^{64}$ There is lot of truth in this simple statement. Leader of the UN is often left alone to fight the pressure and influences. This is the only way to elect the best SG. It is well known that, since P-5 members are the ones electing SG, he has to "please" them or otherwise he will not see the second mandate, as it was in the case of Mr. Boutros Boutros-Ghali that was denied a second term in 1996 after criticizing the Clinton administration for caring more about bloodshed in the Balkans than in Africa. ${ }^{65}$ Wise approach and balancing with P-5 members is something that every SG must be capable of achieving.

As UN High Commissioner for Refugees, Mr. Guterres did a lot on decentralization and overall reform of the UNHCR. Those changes were not just cosmetic - UNHCR is much more efficient and capable organization now than it used to be before he was appointed. ${ }^{66} \mathrm{At}$ the helm of the United Nations, he will have to deal with one opposite issue - fragmentation $^{67}$ in the United Nations system.

Thing to watch after appointing Mr. Guterres will be UN's response to migrant crisis under his lead. UN struggled to deal with the refugee crisis both directly and in coordinating states efforts. As a High Commissioner for Refugees he openly criticized Europe's politics regarding refugee crisis ${ }^{68}$ and on the other side, he also was criticized for "weak" response". 69

Antonio Guterres stated that he will not compare himself with other SGs, ${ }^{70}$ but he can certainly learn a lot from some of his predecessors,

64 http://www.1for7billion.org/news/2016/4/12/antnio-guterres-commentary-fromthe-general-assembly-hearing, last visited 20 June 2016.

65 “Where Are You, Ban Ki-Moon?", http://www.nytimes.com/2013/09/25/opinion/tepperman-where-are-you-ban-ki-moon.html? $r=0$, last visited 21 August 2016.

66 http://www.unhcr.org/4a2dla4b2.pdf, last visited 24 September 2016.

67 M. Novaković, "Moderne tendencije u međunarodnom pravo - fragmentacija i ekspanzija međunarodnog prava", Savremeni međunarodni ekonomski i pravni poredak (ed. Sanja Jelisavac), Institut za međunarodnu politiku i privredu, Beograd 2016, 147.

68 Migrant crisis: EU 'must accept 200,000 refugee', UN says, http://www.bbc. com/news/world-europe-34148891, last visited 28 September 2016.

69 As refugee crisis grows, U.N. agency faces questions, http://www.reuters.com/ article/us-europe-migrants-unhcr-insight-idUSKCNORG13E20150916, last visited 6 July 2016.

70 António Guterres - live commentary from the General Assembly hearing, http:// www. 1 for 7 billion.org/news/2016/4/12/antnio-guterres-commentary-from-the-general-assembly-hearing, last visited 6 July 2016. 
most of all from Mr. Dag Hammarskjöld, a SG who probably coined the term international civil servant ${ }^{71}$ but undoubtedly was exemplary international civil servant, until the tragic death in a plane $\operatorname{crash}^{72}$ in 1961.

\section{CONCLUSION}

Every SG should ask himself the question in the line with J.F. Kennedy's inaugural speech (or Georg St Johns line? ${ }^{73}$ - what he can do for the UN and consequently for the mankind? The first answer that will come to mind to many is probably "not much". However, if he is to do anything or at least to prepare the stage for substantial changes, he has to start from the organization itself. There are numerous cases of corrupted activity within the UN and even some of the candidates such as Irina Bokova $^{74}$ were suspected for this (and failed to provide adequate answer ${ }^{75}$ ). While the UN is weak there are not much chances to make any change. The only candidates that elaborated more extensively on the corruptive issues were Vuk Jeremić ${ }^{76}$ and Miroslav Lajč́ák ${ }^{77}$ but this is not surprising, since they are the only ones coming outside the UN system and it was hard to expect candidates such as Guterres, Bokova or Malcorra to elaborate more on the corruption of the system they have been working within for many years. Integrity is one of the crucial qualities next SG has to possess in order to deal with the corruption within. Regarding Mr. Guterres integrity, being praised by P-5 member sis important $^{78}$ but confidence in his ability expressed by Mr. Kofi Annan ${ }^{79}$ adds additional and more independent dimension. He has overwhelming support by all P-5 members ${ }^{80}$ and the world can just hope that he will put

71 P. Tejler, "Introduction”, Dag Hammarskjöld and Global Governance (ed. Henning Melber), Upsalla 2012, 9

72 S. Williams, Who Killed Hammarskjold?: The Un, the Cold War and White Supremacy in Africa, Hurst \& Co., London 2011.

73 C. Matthews, Jack Kennedy: Elusive Hero, Simon \& Schuster, New York 2011.

74 http://intpolicydigest.org/2016/03/14/controversial-un-candidacy-stirs-world-spast-and-present/, last visited 6 July 2016.

75 Bulgaria: UN Candidate Property Wealth Raises Questions, https://www.occrp. org/en/daily/5078-bulgaria-un-candidate-property-wealth-raises-questions, last visited 7 October 2016.

76 Vision Statement Serbia.

77 Vision Statement Slovakia.

78 “Antonio Guterres: I will serve most vulnerable as UN chief”, http://www.bbc. com/news/world-37576421, last visited 6 October 2016.

79 Ibid.

80 "Portugal's Antonio Guterres set to be UN secretary general", http://www.bbc. com/news/world-37566898, last visited 6 July 2016. 
this favorable situation into good use and react efficiently to the Syria situation, migrant crisis and terrorism on the external and UN reform on the internal plan. Although Mr. Guterres does not like comparison with other SGs, ${ }^{81}$ to achieve all those goals he will need to apply a lot of Hammarskjöld-like governance and leadership.

Future of the appointment procedure of the SG certainly lies within further improvement of transparency and inclusion. Of course, this process has it limits since one cannot expect absolutely open selection process at least in this political constellation and current system. One of the possible improvements would certainly be more clear criteria that candidates must fulfill before even being considered for the SG position. That is very important step that would significantly diminish the possibility of appointment of incompetent SG.

Finally, we have to address one formal aspect regarding SG's mandate and appointment procedure that burdens the independence of SG possibility for second mandate. Second mandate is a very important tool in the hands of the people who are deciding on the re-appointment process and any institution aiming for independence must abolish re-election as possibility. European Court of Human Rights, ${ }^{82}$ in the quest of improving capabilities for protection of human rights in XXI century ${ }^{83}$ adopted this view and abolished second mandate, and that is the path that UN should follow as well.

\section{REFERENCES}

Boutros Boutros-Ghali, Unvanquished, a United Nations-United States Saga, L.B. Tauris Publishers, London - New York 1999.

Harris, D. J., O'Boyle M., Bates E., Buckley C., Law of the European Convention on Human Rights, Oxford University Press, Oxford 2014.

Jovanović, M., Krstić, I. "Ljudska prava u XXI veku - između krize i novog početka", Anali Pravnog fakulteta u Beogradu 4/2009.

Lund, J. S., Pros and Cons of Security Council reform, Center for UN Reform Education, Wayne, New Jersey 2010.

Matthews, C., Jack Kennedy: Elusive Hero, Simon \& Schuster, New York 2011.

81 http://www.1for7billion.org/news/2016/4/12/antnio-guterres-commentary-fromthe-general-assembly-hearing, last visited 6 August 2016.

82 D. J. Harris, M. O'Boyle, E. Bates, C. Buckley, Law of the European Convention on Human Rights, Oxford University Press, Oxford 2014, 105.

83 M. Jovanović, I. Krstić "Ljudska prava u XXI veku - između krize i novog početka", Anali Pravnog fakulteta u Beogradu 4/2009. 
Meisler, S. "UN - The first Fifty Years", The Atlantic Monthly Press, New York 2005.

Milisavljević, B., "Depozitar kod višestranih ugovora", Pravni život $12 / 2012$.

Mundis, D. A., "Practicing International Criminal Law", Careers in International Law (ed. S.A. Swartz), American Bar Association, Chicago.

Norchi, C., "Human Rights: A Global Common Interest", The United Nations: Confronting the Challenges of a Global Society (ed. J. E. Krasno), Lynne Rienner Publishers, London 2004.

Novaković, M., "Moderne tendencije u međunarodnom pravu - fragmentacija i ekspanzija međunarodnog prava", Savremeni međunarodni ekonomski i pravni poredak (ed. Sanja Jelisavac Trošić), Institut za međunarodnu politiku i privredu, Beograd 2016.

Novaković, M., "Position Of The Whistleblowers In The United Nations System 10 Years After Secretary-General's Bulletin On Protection Against Retaliation - How Far Have We Come?", Social Change in the Global World (ed. StraskoStojanovski), Štip 2016.

Sievers, L., Daws, S., The procedure of the UN Security Council, Oxford University Press, Oxford 2014.

Šrlan, T. "Legal status and protection of children in armed conflicts: New tendencies", Bezbednost 3/2012.

Šuković, O., Položaj i uloga generalnog sekretara Ujedinjenih nacija, Institut za međunarodnu politiku i privredu, Beograd 1967.

Tejler, P. "Introduction", Dag Hammarskjöldand Global Governance (ed. Henning Melber), Upsalla 2012.

Waage, H., "The Winner Takes All: The 1949 Island of Rhodes Armistice Negotiations Revisited", Middle East Journal 2/2011.

Weiss, T., "Overcoming the Security Council Reform Impasse: The Implausible versus Plausible", Dialogue on Globalization (Occasional Paper) 14/2005.

Williams, S., Who Killed Hammarskjld?: The Un, the Cold War and White Supremacy in Africa, Hurst \& Co, London 2011.

Article history:

Received: 3. 10. 2016.

Accepted: 28. 11. 2016. 